International Journal of Applied Linguistics \& English Literature

ISSN 2200-3592 (Print), ISSN 2200-3452 (Online)

Vol. 1 No. 6; November 2012

\title{
The Effects of Input Flood and Consciousness-Raising Approach on Collocation Knowledge Development of Language Learners
}

\author{
Elaheh Hamed Mahvelati \\ Department of Language and Humanities Education \\ Faculty of Educational Studies \\ Universiti Putra Malaysia \\ Mobile: 017-2458737 Email: Elahehhamed@yahoo.com \\ Jayakaran Mukundan (Corresponding author) \\ Department of Language and Humanities Education \\ Faculty of Educational Studies \\ Universiti Putra Malaysia \\ 43400 UPM Serdang, Selangor, Malaysia \\ Mobile: 012- 2099717 Fax: 603-89435386 \\ E-mails: jaya@educ.upm.edu.my; jayakaranmukundan@yahoo.com
}

Received: 04-07- 2012

doi:10.7575/ijalel.v.1n.6p.182
Accepted: 14-08- 2012

Published: 01-11- 2012

URL: http://dx.doi.org/10.7575/ijalel.v.1n.6p.182

\begin{abstract}
Many researchers stress the importance of lexical coherence and emphasize the need for teaching collocations at all levels of language proficiency. Thus, this study was conducted to measure the relative effectiveness of explicit (consciousness-raising approach) versus implicit (input flood) collocation instruction with regard to learners' knowledge of both lexical and grammatical collocations. Ninety-five upper-intermediate learners, who were randomly assigned to the control and experimental groups, served as the participants of this study. While one of the experimental groups was provided with input flood treatment, the other group received explicit collocation instruction. In contrast, the participants in the control group did not receive any instruction on learning collocations. The results of the study, which were collected through pre-test, immediate post-test and delayed post-test, revealed that although both methods of teaching collocations proved effective, the explicit method of consciousness-raising approach was significantly superior to the implicit method of input flood treatment.
\end{abstract}

Keywords: collocation, Input flood treatment, Consciousness-raising approach

\section{Introduction}

Traditionally, vocabulary was taught as single items without paying attention to the relationship it had with its surrounding words in a text. Since vocabulary was given the secondary status until the 1980s and 1990s due to the significance of emphasis on syntactic structures in the traditional language teaching (Carter and McCarthy 1988; Henriksen 1999 Bogaards 2001), it was generally treated as a reading or receptive problem. This view is starting to change, and the traditional language teaching methods that only put emphasis on the semantic aspect of words and ignored the collocational fields of each word item have been challenged by Lewis' (1993) Lexical Approach which is at the heart of the current communicative language teaching approach (1990s to the present).

Collocations, which take the central role in Lewis' Lexical approach (1993), have proved to have crucial role in both receptive and productive use of the language for both less advanced and advanced learners in various studies (Cowie, 1992; Farghal and Obiedat, 1995; Wray, 2002; Nesselhauf, 2003; Hsu, 2007; Juknevičienè, 2008; Alsakran, 2011; Farrokh, 2012; Goudarzi and Moini, 2012). Moreover, Fan (2009) asserts that collocational knowledge promotes L2 learners' fluency and accuracy, and makes their writing and speech more understandable 
and natural. Similarly, Carter and McCarthy (1988) point out that knowledge of collocation facilitates English comprehension and production. However, a careful review of the literature indicates that only little research has been done to find out the efficiency of various instructional methods for facilitating collocation learning in a practical domain. In other words, although the need for shifting the focus from single words to the meaningful chunks has long been recognized by many researchers and scholars, the viable ways to develop language learners' knowledge of these chunks have not been explored sufficiently in this body of research.

Collocation learning and teaching research shows that researchers and educational linguists seem to hold two conflicting views on teaching collocations. Some stress the importance of teaching collocations explicitly through consciousness-raising activities (Willis \& Willis, 1996; Nesselhauf, 2003; Ying and Hendricks, 2004; Seesink, 2007; Stoitchkov, 2008), while others assert that implicit collocation teaching can be beneficial for language learners in a practical domain (Ellis, 1997; Nation, 2001; Naggy, 2002). Nevertheless, it is difficult to find studies which directly compare the effects of these teaching approaches on learning collocations. The studies which were conducted by Öztina (2009) and Zaferanieh and Behrooznia (2011) are among those few studies which directly compared the impact of different collocation teaching approaches and suggested useful implications for language teachers. However, there exist some gaps in these studies which are aimed to be filled by the present study. Öztina's (2009) study, for example, only focused on make/do collocations and did not consider the other types of lexical and grammatical collocations which are of great importance for language learners in real-life learning situations. Moreover, Zaferanieh and Behrooznia's (2011) study was limited to investigate the short-term effects of explicit vs. implicit collocation instruction, and did not examine whether they had durable effects.

\subsection{Objectives of the study}

This study aimed at exploring the role of consciousness-raising approach as an explicit method of instruction and input-flood treatment as an implicit method of instruction in learning collocations, and finding out which one can be more beneficial for Iranian EFL learners in the short and long term. The objectives of this study were:

1. to investigate the short-term and long-term effect of consciousness-raising approach on developing both lexical and grammatical knowledge of collocations

2. to examine the impact of input-flood treatment on learning both lexical and grammatical collocations in the short and long term.

3. to compare the short and long-term effectiveness of consciousness-raising approach with input-flood treatment on facilitating the learners' knowledge of collocations.

\subsection{Research Questions}

1. Does consciousness-raising approach help the Iranian EFL learners enhance their knowledge of collocations in the short and long term?

2. Does input-flood treatment help the Iranian EFL learners improve their knowledge of collocations in the short and long term?

3. Are there any significant differences between the input flood treatment and consciousness-raising approach in improving the learners' knowledge of collocations in the short and long term?

\section{Literature Review}

\subsection{What is collocation?}

There are various definitions and interpretations of collocation in the field of lexicon studies, but there is one feature which is shared by all of these definitions and that is the repeated co-occurrence of the strings of words (Bahns, 1993; Nation, 2001; Hsu, 2007; Juknevičienè, 2008).

Collocation was first brought up by Palmer (1933) who insisted on teaching the word partnerships such as tomorrow morning as one linguistic item (Howatt, 1984, p. 238). Palmer (1933), in his monograph Second Interim Report on English Collocations, asserts that it is better and more convenient to learn collocation "as an integral whole or independent entity, rather than by the process of piecing together their component parts" (Palmer, 1933, p. 4). Nevertheless, it is believed that Firth (1957) is the father of collocation since he was the one who introduced and developed the term 'collocation' in field of theoretical linguistics (Martyńska, 2004; Hsu, 2007).

Some researchers and scholars such as Benson et al. (1997), Lewis (2001) and Wei (1999) classify collocations 
International Journal of Applied Linguistics \& English Literature

ISSN 2200-3592 (Print), ISSN 2200-3452 (Online)

Vol. 1 No. 6; November 2012

into two main categories: Lexical collocations and Grammatical collocations. Grammatical collocations are composed of a verb, a noun, or an adjective plus a preposition or a grammatical structure, e.g. apathy toward, in advance, believe in, He sent a book to his brother (Martyńska, 2004; Le, 2010). Lexical collocations, on the other hand, are only comprised of nouns, adjectives, verbs and adverbs, and do not contain grammatical elements, e.g. strong tea, make an impression, an act of violence, highly recommend (Kim, 2009; Wu, Franken and Witten, 2010).

Several studies have been done to figure out the type of collocation errors in the L2 learners' oral and written production. These studies, however, reported different and even contradictory results. More precisely, while some researchers, such as Tong (2004), Li (2005) and Shokouhi and Mirsalari (2010), found out that learners made more grammatical collocational errors than lexical ones, some other researchers, such as Dechert and Lennons (1989) and Mahmoud (2005) proved the opposite. However, it is worth noting that there is a third group of researchers whose studies revealed that both lexical and grammatical collocations were equally problematic for L2 learners (Chen, 2008). These contradictory results indicate that both grammatical and lexical collocations can be the source of difficulty for language learners and there is a need for teaching both types in learning settings. Hence, the present study examined the impact of the implicit versus explicit method of instruction on learning both lexical and grammatical collocations.

It is also important to note that when it comes to assessing the effectiveness of teaching techniques on the learning of collocations, both receptive and productive aspects of the knowledge should be examined. In other words, as Nesselhauf (2005) and Pei (2008) note, collocation knowledge can be described in terms of receptive and productive knowledge since the four language skills are comprised of these two aspects of knowledge. More precisely, as Alsakran (2011) puts it, receptive knowledge is the ability to identify the collocations when they are heard or read (reading and listening skills). Productive knowledge, by contrast, refers to the ability to use them in writing and speech (writing and speaking skills). Therefore, knowing collocations involves both the ability to identify and produce them. Thus, in this study, the learners' knowledge of collocations was assessed at both levels of receptive and productive through gap filling and multiple-choice items.

\subsection{Explicit vs. Implicit teaching and language learning}

The effectiveness of explicit and implicit methods of language teaching has been a subject of controversy for decades. Some researchers, who are the advocates of explicit teaching methods, believe that directing the learner's attention to the target learning objectives in highly structured settings are of great benefit to L2 learners (Schmitt \& zimmerman, 2002; Boers et al., 2006; Ellis \& Bogart, 2007; Taylor et al., 2009).

In contrast, the proponents of implicit teaching methods assert that there is no need for explicit instruction since sufficient exposure to the target items can lead into learning those items (Nagy and Herman, 1987; Ellis, 1997; Gass, 1999; Celce-Murcia, 2001). In other words, they claim that in this kind of instruction, "learners learn the target items as a by-product of reading a text for comprehension of the content rather than for learning that items in that text" (Zaferanieh and Behrooznia, 2011, p. 122). It is also important to note that some of the advocates of implicit teaching methods challenge Krashen's claim (1981) and assert that mere exposure is not sufficient for learning the target features in the input. More precisely, these researchers believe that using some input enhancement techniques, such as input flood and text enhancement, can play a crucial role in drawing learners' attention to the target items and thus enhancing the process of learning (Schmidt, 1990; Sharwood-Smith, 1993).

Moreover, there are some other researchers who believe that the combination of these two approaches can facilitate learners' acquisition (Öztina, 2009; Hunt and Beglar, 2005). In the present study, the effectiveness of both explicit and implicit teaching methods was examined through consciousness-raising approach and input-flood treatment.

\subsection{Learning collocations through input flood vs. consciousness-raising approach}

English collocation has been widely studied from the standpoint of various researchers especially in the last two decades, and the fact that collocations are needed to be integrated into the language syllabus has been accentuated in different studies (Hill, 2000; lin, 2002; Durrant, 2008; Fan, 2009; Motallebzadeh et al., 2011). However, the important question which deals with the best and most effective type of collocation instruction remains unanswered since only a few studies have directly compared different approaches in teaching collocations. Thus, the two instructional methods of consciousness-raising approach (explicit treatment) and input flood (implicit treatment) were selected to be examined in the present study.

Language awareness has been discussed intensively in terms of its level, and identified 'noticing' as one of the 
had sufficient knowledge about their semantic features. In other words, they were not new or difficult words with regard to their semantic features (e.g. "friend," "disappointed," "remember" etc), but posed a challenge to the learners when it came to exploring their collocational fields. These target collocations included the following types:

1. Noun+noun

2. Noun+verb

3. Verb+noun

4. Adjective+noun

5. Adverb+adjective

6. Verb+adverb

7. Noun+ preposition

8. Preposition+noun

9. Adjective+preposition

10. Linking verb collocations (become/get/turn/go collocations)

In addition to the course book, specific materials, which contained the target lexical and grammatical collocations, were used for consciousness-raising and input flood treatments. The reading texts and materials used for the input flood group were followed by various exercises which were aimed to make the subjects see the target collocations many times.

For the consciousness-raising treatment, some books such as "English Collocations in Use" (McCarthy \& O'Dell, 2005) and "Key Words for Fluency" (Woolard, 2004) and a free web-based concordancing tool with the database selected from the Corpus of Contemporary American English (COCA) were used as the sources for teaching collocations. This site can be accessed at http://corpus.byu.edu/coca/.

Finally, three researcher-made collocation tests were used as the pre, immediate and delayed post-test. All the three tests assessed the same target lexical and grammatical collocations which were taught in the experimental groups. However, these collocations were tested in different contexts in the pre, immediate and delayed post-tests. Moreover, it is important to note that these tests measured the subjects' both receptive and productive knowledge of collocations through multiple-choice and gap-filling items. Furthermore, the Cronbach's $\alpha$ formula was used to measure the reliability of the tests and the R-values for the pre, post and delayed post-tests were $0.79,0.81$ and 0.78 respectively.

\subsection{Procedure}

At first, all the participants were asked to take a TOEFL PBT to select those who had roughly the same level of general English proficiency. Then the background questionnaire was administered to ensure that the participants had not received any kinds of collocation instruction before and the concept of collocation was not familiar to them.

Moreover, in the second session, all the participants took the pre-test before the treatment in order to make sure that those who served as the subjects of the study were initially homogeneous with regard to their knowledge of collocations. Finally, the subjects were randomly classified into two experimental groups and one control group.

In one of the experimental groups, collocations were taught implicitly through input flood treatment which involved multiple exposures to the target collocations. In other words, in the input-flood group, the learners were provided with plenty of exemplars of the target collocations in different texts, and they were asked to do the exercises which focus on the gist of those texts rather than the target collocations flooded. However, in the second experimental group, explicit method of consciousness-raising approach was used. More precisely, the teacher tried to draw learners' attentions to word combinations, chunks and specifically to collocations through consciousness-raising activities and web-based concordance activities. In other words, the learners became aware of learning collocations and their importance before the beginning of the treatment. The subjects in the control group, on the other hand, attended their regular English lessons throughout the study and did not receive any implicit or explicit collocation instruction.

Two days after the last session of the treatment, the immediate post-test was administered to the participants in all three groups in order to assess the short-term effect of the treatments on the subjects' collocation knowledge 
International Journal of Applied Linguistics \& English Literature

ISSN 2200-3592 (Print), ISSN 2200-3452 (Online)

Vol. 1 No. 6; November 2012

development, and explore the possible differences between them. Then, in order to examine the long-term effects of the treatments, the participants were asked to take the delayed post-test two weeks later.

\subsection{Data analysis}

The normality tests of Kolmogorow-Smirnov, Shapiro-Wilks and Skewness were performed to find out if the data were normally distributed, and the results revealed that the data had normal distribution. Thus, paired samples t-Test and Anova, with the p-value of .05 , were the statistical tests which were used to answer the questions of the present study. All analyses were conducted using SPSS 18.

\section{Result and discussion}

At first, in order to examine any significant differences among the groups at the beginning of the treatments, a one way analysis of variance was carried out on the pre-test scores. Table 1 indicates descriptive statistics for the pre-test scores.

Table1. Descriptive statistics for pre-test score

\begin{tabular}{llll}
\hline Groups & $\mathrm{N}$ & Mean & $\mathrm{SD}$ \\
\hline Control & 32 & 19.81 & 1.69 \\
\hline Consciousness-raising group & 31 & 19.61 & 1.63 \\
\hline Input-flood group & 32 & 19.53 & 1.82 \\
\hline
\end{tabular}

As Table 2 demonstrates, there were no significant differences among the groups before the treatments administered $(\mathrm{F}(2,92)=.227, \mathrm{p}>.05)$.

Table 2. One-way Anova for pre-test scores

\begin{tabular}{lccccc}
\hline & Sum of squares & $d f$ & Mean square & F & Sig \\
\hline Between group & 1.33 & 2 & .669 & .227 & .798 \\
\hline Within group & 271.69 & 92 & 2.95 & & \\
\hline Total & 273.03 & 94 & & & \\
\hline
\end{tabular}

Then in order to answer the first and second research questions which deal with the short and long term effects of input flood treatment and consciousness-raising approach on the learners' collocation knowledge development, paired samples t-Test was used for each teaching method. The within group comparison from pre-test to post-tests revealed that the differences between the pre-test and the immediate and delayed post-test scores were statistically significant in both methods $(\mathrm{p}=.000<.05)$. Hence, the short and long term effects of both teaching methods on the learners' collocational knowledge development were proved significantly positive.

Furthermore, the statistical analyses showed that there was a significant decrease in the learners' scores from the immediate post-test to the delayed post-test in both experimental groups $(\mathrm{p}=.000<.05)$. Although the learners forgot some collocations they had learned in two-week time between the immediate post-test and delayed post-test, the statistically significant difference between their pre-test scores and delayed post-test scores proved that both treatments had durable effects.

The findings of this part are in line with a number of studies (Adolphs \& Durow, 2004; Siyanova \& Schmitt, 2008; Öztina, 2009; Zaferanieh and Behrooznia, 2011) which proved the effectiveness of both implicit and explicit methods of teaching lexical items in ESL/EFL learning settings. Similarly, Beltran (2004) and Laufer (2006) proved that both implicit and explicit teaching methods were beneficial in the learning of target lexical items.

Moreover, the results are consistent with the claim supported by some researchers, such as Skehan (1998), and Wong (2005) that both explicit teaching and input flood are among the effective factors which can "promote more 'input' into 'intake' by raising students consciousness" (Zhang, 2012, p. 583) and thus facilitate more comprehensible output (Ellis, 1999). 


\section{International Journal of Applied Linguistics \& English Literature}

ISSN 2200-3592 (Print), ISSN 2200-3452 (Online)

Vol. 1 No. 6; November 2012

As it was mentioned before, the main concern of the present study was to compare implicit treatment in the form of an input flood with explicit treatment in the form of consciousness-raising approach to find out which one can result in more significant improvement in terms of the knowledge of collocations. Hence, the possible differences between these two approaches were dealt with in the third research question. Table 3 demonstrates the descriptive statistics for immediate and delayed post-tests.

Table 3. Descriptive statistics for immediate and delayed post-tests

\begin{tabular}{lcccccc}
\hline & \multicolumn{3}{c}{ Immediate post-test } & \multicolumn{3}{c}{ Delayed post-test } \\
\hline Groups & $\mathrm{N}$ & Mean & $\mathrm{SD}$ & $\mathrm{N}$ & $\mathrm{Mean}$ & $\mathrm{SD}$ \\
\hline Consciousness-raising group & 31 & 29.82 & 1.72 & 31 & 26.56 & 1.78 \\
\hline Input-flood group & 32 & 25.45 & 4.15 & 32 & 22.34 & 3.35 \\
\hline Control & 32 & 19.96 & 1.66 & 32 & 19.84 & 1.65 \\
\hline
\end{tabular}

In this part, in order to answer the third research question, one way Anova was used and its results on the immediate and delayed post-test scores are represented in tables 4 and 5.

Table 4. One-way Anova for immediate post-test scores

\begin{tabular}{lccccc}
\hline & Sum of squares & $d f$ & Mean square & F & Sig \\
\hline Between group & 1537.48 & 2 & 768.74 & 99.55 & .000 \\
\hline Within group & 710.42 & 92 & 7.72 & & \\
\hline Total & 2247.90 & 94 & & & \\
\hline
\end{tabular}

As Table 4 reveals, there was a significant difference between the immediate post-test scores of the groups (F (2, $92)=99.55, \mathrm{p}<.05)$. Hence, Turkey's HSD post hoc was performed and the results indicated that the subjects' scores in both experimental groups were significantly higher than the scores of the subjects in the control group. Moreover, a significant difference was observed between the consciousness-raising and input-flood groups. More precisely, the statistical results proved the superiority of consciousness-raising approach over the input-flood treatment in improving learners' knowledge of collocations in short term.

Table 5. One-way Anova for delayed post-test scores

\begin{tabular}{lccccc}
\hline & Sum of squares & $d f$ & Mean square & F & Sig \\
\hline Between group & 725.04 & 2 & 362.52 & 63.01 & .000 \\
\hline Within group & 529.30 & 92 & 5.75 & & \\
\hline Total & 1254.35 & 94 & & & \\
\hline
\end{tabular}

Similarly, the results of one-way Anova on the learners' delayed post-test scores (Table 5) showed a statistically significant difference between the groups' performance $(\mathrm{F}(2,92)=63.01, \mathrm{p}<.05)$, and Turkey's HSD post hoc multiple comparison reveals the same results observed for the immediate post-test.

In sum, the between group comparison indicated that although both experimental groups outperformed the control group in both short and long term, their performance on the immediate and delayed post-tests was significantly different. More precisely, the results revealed that the explicit method of consciousness-raising approach improved the learners' collocation knowledge more effectively than the input-flood treatment in both short and long term.

These results lend support to the findings of Lin (2002), Sun and Wang (2003), Ghonsooli et al., (2008) and Stoitchkov (2008) that explicit collocation instruction has a prominent role in learners' collocation knowledge 
enhancement. More precisely, the findings concerning the superiority of the consciousness-raising approach as an explicit method over the input-flood treatment as an implicit method in improving learners' collocation knowledge are consistent with Laufer's (2006) and Zaferanieh and Behrooznia's study (2011) that learners benefited more from the explicit collocation instruction methods. These studies stress the importance of attention and suggest that although language learners do extend their knowledge of collocation through implicit instruction, their progress can be considerably more significant when they receive more explicit instruction.

Similarly, Rassaei and Karbor (2012) compared the effectiveness of three types of awareness raising techniques: textual enhancement, input enrichment, and form comparison on the acquisition of collocations and found out that the form comparison technique was the most effective one since it was the most explicit teaching method. In other words, their findings suggest that the more explicitly the learners' attention is drawn, the more effectively they can learn the target collocations since, as Wu, Franken and Witten (2010) also note, calling learners' attention to the existence of the target items is the first and most important step. Hence, the most effective teaching method is the one which can raise the highest level of awareness and attention.

Nesselhauf (2003) and Boonyasaquan (2009) also point out that the habit of noticing collocations should be encouraged in learners whenever they learn English. This habit can be developed by encouraging them to record language patterns and collocations in their memory, and as Wray (2002) puts it, this is the main role of the teachers. Additionally, Schmidt (2001) points out that understanding virtually every aspect of second language acquisition requires paying enough attention.

Similar to the studies above, the superior performance of the subjects in the consciousness-raising group proved the importance of attention and noticing in the learning of collocations. In particular, the learners in the consciousness-raising group outperformed the ones in the input flood group since they were explicitly asked to pay attention to the collocational fields of the words. In other words, it can be argued that the poorer performance of the input-flood group was partially due to lack of enough awareness and therefore their failure to notice the target collocations.

\section{Conclusion}

This study aimed at investigating the effectiveness of consciousness-raising approach and input flood treatment on the learning of both lexical and grammatical collocations. The results of the study revealed that collocations could not be easily learned through the normal course of teaching sessions without any instructional techniques. In other words, the superiority of the learners' performance in both experimental groups over the control group proved the necessity of teaching collocations in class. Furthermore, the statistically significant difference between the performances of the two experimental groups demonstrated that more explicit and focused instruction where the teacher explicitly drew learners' attention to the target collocations was more effective than the implicit method of input-flood treatment.

The findings of the present study seem to have some important educational implications for language teachers. Since the role of collocations in the performance of EFL/ESL learners has been proved significantly effective, raising learners' awareness of collocations is of considerable importance. In other words, teachers should use awareness raising techniques with the highest level of explicitness to help learners notice collocations, store them in their working memory in an organized way and encourage learners' independence because of the fact that developing collocational knowledge is a long process. Furthermore, in this study in addition to traditional methods of teaching collocations (e.g. using dictionaries and source books), web-based concordance activities were also used as the explicit instructional method, and this combination was proved highly effective. Using concordancing materials give the learners the chance of learning collocational fields of words in authentic, up-to-date context. Additionally, such a method can give a more active role to the learners and help them to learn a set of skills, such as problem solving, discovery and exploring, which are necessary for developing independent language learning abilities. Further research is required to examine the effectiveness of these teaching approaches (input flood vs. consciousness-raising approach) on collocation knowledge development of learners with different levels of language proficiency and learning styles. Moreover, making some adjustments to the treatments used in this study could lead to more useful findings. For example, the efficacy of a third treatment type which combines input flood with consciousness-raising approach can be investigated in another study in order to find out the most efficient method for teaching collocations. Finally, since the transfer of collocational patterns from L1 is one of the major sources of error for L2 learners (Gabrys- Biskup, 1992), future research is needed to measure the effectiveness of these teaching methods with regard to learners' knowledge of congruent and non-congruent collocations. 
International Journal of Applied Linguistics \& English Literature

ISSN 2200-3592 (Print), ISSN 2200-3452 (Online)

Vol. 1 No. 6; November 2012

\section{References}

Adolphs, S., \& Durow, V. (2004). Social-Cultural Integration and the Development of Formulaic Sequences. In N. Schmitt (Ed.), Formulaic Sequences (pp. 107-126). Amsterdam, Netherlands: John Benjamins.

Alsakran, R. A. (2011). The productive and receptive knowledge of collocations by advanced Arabic-speaking ESL/EFL learners. M.A. dissertation, Colorado State University, United States -- Colorado. Retrieved June 1, 2012, from Dissertations \& Theses: Full Text.(Publication No. AAT 1497925).

Anderson, R. C., Wilson, P., \& Fielding, L. (1988). Growth in reading and how children spend their time outside of school. Reading Research Quarterly, 23, 285-303.

Bahns, J. (1993). Lexical collocation: a contrastive view. ELT Journal 47(1), 56-63.

Beltran, R. C. (2004). The effects of focus on form in the teaching of Spanish- English false friends. RESLA, 17-18, 65-79.

Benson, M., Benson, E. \& Ilson, R. (1997). The BBI dictionary of English word combinations ( $2^{\text {nd }}$ edition). Amsterdam, The Netherlands: John Benjamins Publishing Company.

Boers, F., Eyckmans, J., Kappel, J., Stengers, H., \& Demecheleer, M. (2006). Formulaic sequences and perceived oral proficiency: Putting a lexical approach to the test. Language Teaching Research, 10, 245-61.

Bogaards, P. (2001). Lexical units and the learning of foreign language vocabulary. Studies in Second Language Acquisition 23 (3), 321-343.

Carter, R. \& McCarthy, M. (1988). Vocabulary and language teaching. New York: Longman.

Celce-Marcia, M. (2001). Teaching English as a Second or Foreign Language. Boston, MA: Heinel \& Heinel Publishers, a Division of Wadsworth, Inc.

Choudhery, A.S. (2010). Teaching Vocabulary in the ESL/EFL Classroom: Central Pedagogical Issues. MJAL 2 , 306-316

Cowie, A. P. (1992). Multiword lexical units and communicative language teaching. In P. Arnaud \& H. Bejoint (Eds.), Vocabulary and applied linguistics (pp. 216-331). London: Macmillan Academic and Professional LTD. Durrant, Ph. (2008). High frequency collocations and second language learning. Thesis submitted to the University of Nottingham for the degree of Doctor of Philosophy.

Ellis, R. (1997). SLA research and language teaching. Oxford University Press, Oxford.

Ellis, R. (1999). The study of second language acquisition. Shanghai: Shanghai Foreign Education Press.

Ellis, R. (2001). Introduction: Investigating form-focused instruction. Language Learning, 51 (1), 1-46.

Ellis, N. C. \& Bogart, P. (2007). Speech and Language Technology in Education: The Perspective from SLA

Research and Practice. In Proceedings of the SlaTE Workshop on Speech and Language Technology in Education ISCA Tutorial and Research Workshop, Farmington, Pennsylvania USA, October 1-3, 2007.

Fan, M. (2009). An exploratory study of collocational use by ESL students - A task based approach. System 37 , 110-123.

Farghal, M., \& Obiedat, H. (1995). Collocations: A neglected variable in EFL.IRAL, 33(4), 313-331.

Farrokh, P. (2012). Raising Awareness of Collocation in ESL/EFL Classrooms. Journal of Studies in Education. 2 (3), 55-74.

Firth, J.R. (1957) Papers in Linguistics: 1934-1951. London: Oxford University Press.

Gabyrs-Biskup, D. (1992). L1 Influence on Learners' Renderings of English Collocation. A Polish/German Empirical Study. In P.J. Arnauld and H. Benjoint (Eds.), Vocabulary and Applied Linguistics (pp. 85-93). London: Macmillan.

Gass, S. (1997). Input, Interaction, and the Second Language Learner, Erlbaum.

Gass, S. (1999).Incidental vocabulary learning: Discussion. Studies in Second Language Acquisition, 21,3 19-333.

Ghonsooli, B., Pishghadam, R. \& Mahjoobi. A. M. (2008). The Impact of collocational Instruction on the Writing Skill of Iranian EFL Learners: A Case of Product and Process Study. Iranian EFL Journal, (2), 36-59.

Goudarzi, Z. \& Moini, M. R. (2012). The Effect of Input Enhancement of Collocations in Reading on Collocation Learning and Retention of EFL Learners. International Education Studies, 5(3), 247-258.

Henriksen, B. (1999). Three dimensions of vocabulary development. Studies in Second Language Acquisition 21 (2), 303-317.

Hernandez, T. (2008). The Effect of Explicit Instruction and Input Flood on Students9 Use of Spanish Discourse Markers on a Simulated Oral Proficiency Interview. Hispania, Vol. 91(3), pp. 665-675

Hill, J. (2000). Revising priorities: From grammatical failure to collocational success. In Teaching Collocation, ed. Michael Lewis, 47-70. Hove, England: Language teaching Publications.

Howatt,A. P. R. (1984). A history of English language teaching. Oxford:Oxford University Press.

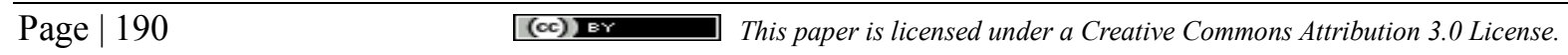


International Journal of Applied Linguistics \& English Literature

ISSN 2200-3592 (Print), ISSN 2200-3452 (Online)

Vol. 1 No. 6; November 2012

Hsu, J.(2007). Lexical collocations and their relation to the online writing of Taiwanese college Englishmajors . Electronic Journal of Foreign Language Teaching 4(2): 192-209.

Hsu, J-Y., \& Chiu, C.-Y. (2008). Lexical Collocations and their Relation to Speaking Proficiency of College EFL Learners in Taiwan. Asian EFL Journal, 10. Retrieved December 10, 2009, from

http://www.asian-efl-journal.com/March_08_jth.php.

Hulstijn, J., Hollander, M., \& Greidanus, T. (1996). Incidental vocabulary learning by advanced foreign language students: The influence of marginal glosses, dictionary use, and reoccurrence of unknown words. The Modern Language Journal, 80, 327-339.

Hunt, A \& Beglar, D 2005, 'A framework for developing EFL reading vocabulary', Reading in a Foreign Language, vol. 17(1), pp. 23-59.

Juknevičienè, R. (2008). Collocations with High-Frequency Verbs in Learner English: Lithuanian Learners vs Native Speakers. Retrieved December 23, 2009, from:

http://www.leidykla.vu.lt/fileadmin/Kalbotyra_3/59_3/119-127.pdf

Junying, Zh. \& Xuefei, W. (2007). Chunking-an effective approach to vocabulary teaching and learning in college classrooms. Retrieved January 13, 2010, from:

http://docs.google.com/viewer?a=v\&q=cache:XfrPjPREsHcJ:www.celea.org.cn/teic/73/73-79.pdf+Junying+\%26

+ Xuefei, $+2007 \% 2 B+$ collocation\&hl=en\&pid=bl\&srcid=ADGEEShssQsJcClB5ALHiL15madAouR8QtZHplxf9 3c8SO3leZtLj1TCVzqtXSub_PaUDKnipTrj8pZuUx_iW6sI7zBQGm_E7uGmzpwVIwH9-qK_ajC7cPji7Lkg6 CLqhPxRUPqWMLf\&sig=AHIEtbQjA1hGBdO7YPLoyJY9dzNzfNbSgg

Kim, D. H. (2009). A study on the use of lexical collocations of Korean heritage learners: identifying the sources of errors. A dissertation submitted to the graduate school and research in the fulfillment of the requirements for the degree master of arts, Anadolu University Institute of Educational Sciences.

Krashen, S. D. (1981). Second language acquisition and second language learning. Oxford: Pergamon Press. Krashen, S.D. (1989). We acquire vocabulary and spelling by reading: Additional evidence for the Input Hypothesis. The Modern Language Journal, 73, 440-464.

Laufer, B. (2006). Comparing focus on form and focus on forms in second language vocabulary learning. The Canadian Modern Language Review, 63 (1), 149-166.

Le, T. H. (2010). Learning lexical collocations with concordancing and scaffolding. Retrieved December 20, 2010 from:

http://scripties.let.eldoc.ub.rug.nl/FILES/root/Master/DoorstroomMasters/ToegepasteTaalwetens/2010/Le/MA_1 938851_T_H_Le.pdf

Lewis, M. (1993). The lexical approach. Hove: Language Teaching Publications.

Lewis, M. \& Hill, J. (1997). A dictionary of selected collocations. Hove, UK: Language Teaching Publications.

Lewis, M. (2000). Language in the lexical approach. In M. Lewis (ed), Teaching collocation: Further

developments in the lexical approach (pp.155-184). London: Language Teaching Publications.

Lewis, M. (2001). There is nothing as practical as a good theory. In Michael Lewis (ed.). Teaching collocation:

Further developments in the lexical approach, 10-27. London: Language Teaching Publications.

Lin, Y. P. (2002). The effects of collocation instruction on English vocabulary development of junior high school students in Taiwan. Unpublished master thesis, National Kaohsiung Normal University, Kaohsiung, Taiwan.

Martyńska, M. (2004). Do English Language Learners Know Collocations?. Retrieved February 10, 2010, from: http://inveling.amu.edu.pl/pdf/malgorzata_martynska_inve11.pdf

McCarthy, M. \& O'Dell, F. (2005). English Collocations in Use. Cambridge, UK: Cambridge University Press.

Motallebzadeh, Kh., Beh-Afarin, R., Rad, D. S., (2011). The Effect of Short Message Service on the Retention of Collocations among Iranian Lower Intermediate EFL Learners. Theory and Practice in Language Studies, Vol. 1(11), pp. 1514-1520.

Nagy, W.E., \& Herman, P.A. (1987). Breadth and depth of vocabulary knowledge: Implications for acquisition and instruction. In M.G. McKeown \& M.E. Curtis (Eds.), The Nature of Vocabulary Acquisition (pp. 19-35).

Hillsdale, N.J.: Lawrence Erlbaum.

Nakata, T. (2007). English collocation learning through meaning-focused and form- focused tasks. Proceedings of the 11th Conference of Pan-Pacific Association of Applied Linguistics, 154-168. Retrieved January 15, 2010 from http://www.paaljapan.org/resources/proceedings/PAAL11/pdfs/13.pdf

Nation, I. S. .P. (1990). Teaching and learning vocabulary. Rowley, MA: Newbury House.

Nation, I.S.P. (2001). Learning vocabulary in another language. Cambridge: Cambridge University Press. Nesselhaulf, N. (2003). The use of collocations by advanced learners of English and some implications for teaching. Applied Linguistics, 24(2), 223-242. 
International Journal of Applied Linguistics \& English Literature

ISSN 2200-3592 (Print), ISSN 2200-3452 (Online)

Vol. 1 No. 6; November 2012

Nesselhauf, N. (2005). Collocations in a learner corpus. Amsterdam: John Benjamins.

Öztina, S. (2009). Effects of Input Flood and Negative Evidence on Learning of Make/Do Collocations: A Study with Seventh Grade Turkish EFL Students. A dissertation submitted to the graduate school and research in the fulfillment of the requirements for the degree master of arts, Anadolu University Institute of Educational Sciences.

Palmer, H.E. (1933) Second Interim Report on English Collocations. Tokyo: Kaitakusha.

Pei, C. (2008). Review of empirical studies on collocation in the field of SLA. Retrieved May 2, 2010 from: http://www.celea.org.cn/teic/82/82-72.pdf

Rassaei and Karbor (2012). The effects of three types of attention drawing techniques on the acquisition of English collocations. International Journal of Research Studies in Language Learning 1, 1-14.

Schmidt, R. (1990). The role of consciousness in second language learning. Applied Linguistics 11, 129-158.

Schmidt, R. (2001). Attention. In P. Robinson (Ed.), Cognition and second language instruction (pp. 3-32). New York: Cambridge University Press.

Schmitt, N., \& Zimmerman, C. B. (2002). Derivative word forms: What do learners know? TESOL Quarterly, $36(2), 145-171$.

Seiba, Z. (2001). Classroom Instruction and Second Language Acquisition: The effect of explicit form-focused instruction on L2 learners ${ }^{\text {ee }}$ linguistic competence. A doctoral dissertation presented to the University of Mississippi, Oxford, Mississippi.

Sharwood-Smith, M. (1993). Input enhancement in instructed SLA: Theoretical bases. Studies in Second Language Acquisition, 15(2), 165-179.

Siyanova, A., \& Schmitt, N. (2008). L2 Learner Production and Processing of Collocation: a Multi-Study

Perspective. Canadian Modern Language Review, 64(3),pp. 429-458.

Skehan, p. (1998). A cognitive approach to language learning. Oxford: Oxford University Press.

Stoitchkov, R. (2008). Building collocation competence. Retrieved April 15, 2010 from:

http://www.beta-iatefl.org/1749/blog-publications/building-collocation-competence/

Sun, Y.C., \& Wang, L.Y. (2003). Concordancers in the EFL Classroom: Cognitive Approaches and Collocation Difficulty. Computer Assisted Language Learning, 16 (1), 83-95.

Taylor, D. B., Mraz, M., Nichols, W. D., Rickelman, R. J. \& Wood, K. D. (2009). Using Explicit Instruction to Promote Vocabulary Learning for Struggling Readers. Reading \& Writing Quarterly: Overcoming Learning Difficulties, 25:2-3, 205-220.

Wei, Y. (1999). Teaching collocations for productive vocabulary development. Paper presented at the Annual Meeting of the Teachers of English to Speakers of Other Languages. New York.

White, J.P. (2008). The effect of input-based instruction type on the acquisition of Spanish accusative CLITICS. A dissertation submitted to thedepartment of Modern Languages and Linguistics in partial fulfillment of the requirements for the degree of Doctor of Philosophy. Florida State University.

Williams, J. \& Evans, J. (1998). What kind of focus and on which forms? In Doughty and Williams (Eds.), 139-155.

Willis, D. and Willis, J (1996). Consciousness-raising activities in the language classroom. In J. Willis \& D. Willis (Eds.), Challenge and Change in Language Teaching (pp. 63-76). Oxford: Heinemann.

Wong, W. (2005). Input enhancement: From theory and research to the classroom. Boston: McGraw-Hill. Woolard, G. (2004). Key Words for Fluency: Upper-IntermediateCollocation Practice. London:Thomson ELT. Wray, A. (2002). Formulaic language and the lexicon. Cambridge, UK: Cambridge University Press.

Wu, S., Franken, M. \& Witten, I. H. (2010). Supporting collocation learning with a digital library. Computer Assisted Language Learning, 23(1), 87-110.

Ying, Y. \& Hendricks, A. (2004). Collocation awareness in the writing process. Reflections of English Language Teaching, 3, 51-78.

Zaferanieh, E. \& Behrooznia, S. (2011). On the Impacts of Four Collocation Instructional Methods: Web-Based Concordancing vs. Traditional Method, Explicit vs. Implicit Instruction. Studies in Literature and Language Vol. 3(3), pp. 120-126.

Zhang, S. (2012). Promoting noticing in EFL classroom. Theory and Practice in Language Studies, 2(3), pp. $579-584$. 